\title{
Growth, mortality and turnover rates of a small detritivorous fish
}

\author{
Shaun K. Wilson* \\ Department of Marine Biology and Aquaculture, James Cook University, Townsville, Queensland 4811, Australia \\ Present address: School for Field Studies, Centre for Marine Resource Studies, Turks and Caicos Islands \\ Correspondence address: c/o 10 Federal Street, Suite 24, Salem, Massachusetts 01970-3876, USA
}

\begin{abstract}
Growth, mortality and density estimates of the blenny Salarias patzneri were used to quantify turnover rates of a small-bodied detritivorous fish. Turnover rates of $S$. patzneri were then compared with prominent scarids and acanthurids, to assess the relative significance of small detritivores to secondary production on coral reefs. Instantaneous mortality, estimated from growth parameters $\left(L_{\infty}=5.10, K=3.25, t_{0}=0.10\right)$, suggests that less than $99 \%$ of the $S$. patzneri population survives for more than $1 \mathrm{yr}$. Despite their small body size, high mortality rates combined with high densities give $S$. patzneri high annual biomass turnover rates that are similar to larger-bodied acanthurids and scarids. Dietary analysis determined that all post-settlement $S$. patzneri, from juveniles to the largest adults, are detritivorous. The high turnover rates and diet of S. patzneri emphasize the importance of small-bodied fish and detritus to coral reef trophodynamics.
\end{abstract}

KEY WORDS: Coral reef trophodynamics $\cdot$ Secondary production $\cdot$ Growth $\cdot$ Mortality $\cdot$ Body size Turnover rates $\cdot$ Detritivory $\cdot$ Blenniidae

\section{INTRODUCTION}

Detritus and detritivorous fish feeding within the epilithic algal matrix (EAM) represent an important component of food webs on coral reefs (Wilson et al. 2003). Recent studies based on EAM-feeding fish suggest that many of the species previously classified as herbivores are actually detritivores (Wilson et al. 2003). In addition, it appears that a large proportion of these EAM-feeding fish are of a relatively small body size (Wilson 2001a). As small body size infers high metabolic rate and energy requirements (Clarke \& Johnston 1999), high abundances of small-bodied detritivores may have a disproportionately large impact on dietary resources within the EAM, relative to their larger-bodied counterparts. Indeed, Hatcher (1981) found that small fish from the families Pomacentridae and Blenniidae can be responsible for removing more material from the EAM than the much larger-bodied scarids and acanthurids.
Despite the undeniable significance of small-bodied detritivorous fish to ecological processes on coral reefs, no studies have attempted to quantify the rate at which small-bodied fish convert detritus to biomass and how this biomass may be transferred to higher trophic levels. Several studies have provided information on the density or biomass of herbivorous and detritivorous fishes (e.g. Townsend \& Tibbetts 2000, Gust et al. 2001, Sluka \& Miller 2001); however, these static measures do not describe the rates at which species with different life histories transfer energy to secondary consumers. Turnover rates that calculate the time taken for the standing biomass of fish to be replaced may address this problem, and this process can be approximated by multiplying standing biomass by mortality rates (Marnane 2001). Comparing turnover rates of different species at the same location can then be used to assess the relative importance of different taxa within the same feeding guild. Comparisons of this nature must however be made cautiously, as although demo- 
graphic variables such as the growth rate coefficient $(K)$, asymptotic length $\left(L_{\infty}\right)$ and maximum age $\left(T_{\max }\right)$ can be used to estimate mortality (Pauly 1980, Hoenig 1983), these variables do not describe other aspects of life history, such as reproductive lifetime (Choat \& Robertson 2002), that may also influence trophodynamic processes.

Nonetheless, calculating turnover rates based on mortality estimates does provide a preliminary means of comparing the relative contribution of different species to higher trophic levels. Life history traits and parameters such as growth, mortality and density estimates of large-bodied EAM-feeding fish have been investigated for numerous species of scarids and acanthurids (see Choat \& Robertson 2002); however, demographic data for smaller-bodied EAM-feeding fish are largely restricted to pomacentrids (e.g. Worthington et al. 1995, Meekan et al. 2001).

A taxonomic group of small fish likely to play an important role in coral reef trophodynamics is the salariin blennies. These small-bodied fish are often in high densities on reefs, accounting for 20 to $50 \%$ of individuals in fish assemblages feeding on the EAM in some locations (Townsend \& Tibbetts 2000, Wilson 2001a). However, aside from a few studies based on length frequency information (Russ \& St John 1988, Labelle \& Nursall 1992), there is no information on the growth, mortality or turnover rates of these species on coral reefs. Although otoliths have been used to estimate growth rates in several blennioid species from temperate regions (Stephens et al. 1970, Milton 1983, Stepien 1990, Santos et al. 1995), they have yet to be used to estimate age and growth in tropical salariin blennies. Furthermore, whilst data from adult salariin blennies gut contents indicate that they are detritivores (Wilson 2000, Wilson et al. 2001, Depczynski \& Bellwood 2003), it is unknown whether diet changes during ontogeny or among different size classes. It has been suggested that many of the fish that feed on the EAM as adults are actually carnivores as juveniles, when growth rates are the most rapid (see Choat 1991). The trophic status of both adult and juvenile blennies needs to be clarified before inferences can be made about the trophodynamic role of a species within an ecosystem.

This study will use otolith increments to estimate growth, age and mortality of the salariin blenny Salarias patzneri, then combine this information with abundance estimates to calculate turnover rates. Diet of juvenile and adult fish will also be assessed to determine if there are any ontogenetic changes. The importance of $S$. patzneri to coral reef food webs will then be examined by comparing turnover rates of $S$. patzneri to other prominent detritivores and herbivores. As such, this study will improve our understanding of the role that blennies and small fish play in coral reef trophodynamics.

\section{MATERIALS AND METHODS}

Samples of the salariin blenny Salarias patzneri were collected from the Lizard Island lagoon $\left(14^{\circ} 40^{\prime} \mathrm{S}\right.$, $145^{\circ} 28^{\prime} \mathrm{E}$ ) during the Austral winters (June to August) of 1997, 1998 and 2000, summers (December to February) of 1999 and 2000, and spring (September to October) of 1997. All fish were collected using the anesthetic clove oil (Munday \& Wilson 1997) and euthanized in ice water slurry. The total (TL) and standard (SL) lengths of each fish were measured to the nearest $0.1 \mathrm{~mm}$ using calipers and wet weight was measured to the nearest $0.01 \mathrm{~g}$ using a digital balance.

Diet. To assess changes in diet with age, the contents from the alimentary canal of 79 Salarias patzneri, with SLs of between 15.9 and $58.8 \mathrm{~mm}$, were analyzed. Material ingested by fish was removed from the anterior third of the alimentary canal, spread evenly over a glass dish and examined under a compound microscope at $40 \times 10$ magnifications. For each sample, 5 randomly placed transects, each with 10 points, were superimposed on the evenly spread gut contents using a graduated eye piece that was fitted to the microscope. Items observed directly under each transect point were then identified and categorized as detritus, inorganic sediment, filamentous algae, blue-green algal filament, diatoms and invertebrates. Results were expressed as a percentage of total points (50) for each dietary category. Ingested items were easily identified at $40 \times 10$ magnifications as $S$. patzneri lacks a gizzard and oral or pharyngeal teeth that may be used to triturate dietary items (Wilson 2001b). Data were analyzed by placing fish into $10 \mathrm{~mm}$ standard length classes and a Kruskal-Wallis test was used to assess if there was any change in diet among fish from different size classes. Dietary categories were entered as dependent variables and Bonferroni corrections were used to adjust alpha values for multiple comparisons.

Growth, mortality and turnover rates. The age of each fish was estimated by counting the number of opaque bands on sectioned and polished otoliths. Sagital otoliths were removed from each fish, cleaned in fresh water and mounted on a transparent slide with thermoplastic glue. A transverse section of the otolith was made by grinding away the distal ends of the otolith by hand, initially using sandpaper (P1200), then progressively finer grades of lapping film $(9 \mu \mathrm{m}, 3 \mu \mathrm{m})$. Each otolith was ground so that the central rings were visible, then given a final polish with aluminium powder and embedded in crystal bond. The sectioned and polished otolith was read under a compound microscope at $400 \times$ magnification. Dark rings on the otolith were counted from the primordium along the longest axis to the perimeter. Each otolith was counted 
twice, with at least 1 wk between each reading. The mean count was then used as an estimate of age. If the coefficient of variation from the 2 initial otolith readings was greater than $10 \%$, the otolith was read a third time. If the coefficient of variation was still greater than $10 \%$, the otolith was discarded. The otoliths from 109 Salarias patzneri, with SLs between 11.0 and $58.8 \mathrm{~mm}$, met these criteria; however, otoliths from 5 fish were excluded from the data set, due to excessive variation in age estimates. Fish excluded from growth analyses had SLs of 15.9, 31.3, 39.9, 48.5 and $54.4 \mathrm{~mm}$.

To evaluate the time period represented by bands on otoliths 5 Salarias patzneri, with SLs between 15.2 and $23.2 \mathrm{~mm}$, were collected from the lagoon at Lizard Island for validation experiments. The fish were placed in an aquarium, with aeration, and immersed in a solution of tetracycline $\left(1.25 \mathrm{~g} \mathrm{l}^{-1}\right)$, in darkness, for $24 \mathrm{~h}$. After treatment with tetracycline, the fish were placed in an outdoor aquarium, and maintained under natural diel light cycle and with natural food resources for $12 \mathrm{~d}$. Natural food was provided in the form of freshly collected rocks containing EAM, which were replaced every 3 to $4 \mathrm{~d}$.

Age estimates from otoliths were plotted against SLs and a von Bertalanffy growth curve was fitted to the data. Age estimates were converted to years and growth parameters from the von Bertalanffy model were entered into the Pauly (1980) equation to estimate instantaneous mortality. Instantaneous mortality was also estimated using the Hoenig (1983) equation and the age, in years, of the oldest fish encountered. Mortality $(Z)$ was used to estimate annual survival rate, using the formulae: Survival $(\%)=100 \mathrm{e}^{(-Z)}$, where e is the base of the natural logarithm (see King 1995).

Estimates of Salarias patzneri instantaneous mortality were converted to a percentage and multiplied by $S$. patzneri biomass to estimate the yearly turnover rate of this species. Underwater visual census was used to estimate the biomass of $S$. patzneri. Nine $2 \times$ $50 \mathrm{~m}$ transects, on reefs within the Lizard Island lagoon, were censused during August 1998 and February 1999. The total length of all $S$. patzneri seen on transects was estimated and converted to weight using the length-weight relationship derived from fish used for aging and gut content analyses. Total length was used to estimate the size of fish, as it was easier to assess than SLs when fish were observed on transects. Previous assessment of the accuracy of total length estimates of blennies had demonstrated that estimates were $98 \pm 1 \%$ of the actual total length (Wilson 2001a).

To assess the trophodynamic significance of Salarias patzneri turnover rates, the turnover rates of several of the most common detritivorous and herbivorous fish found at Lizard Island were calculated. Using the
Hoenig (1983) equation and maximum age estimates of fish collected from reefs around Lizard Island (Choat \& Axe 1996, Choat et al. 1996), instantaneous mortality was estimated for Acanthurus lineatus (Linnaeus), Chlorurus schlegeli (Bleeker), Chlorurus sordidus (Forsskål), Ctenochaetus striatus (Quoy \& Gaimard), Naso unicornis (Forsskål) and Zebrasoma scopas (Cuvier). Density and size estimates of these species on the crest of exposed and semi-exposed reefs around Lizard Island, where their density is high (Clements 1991, Gust et al. 2001), were provided by J. H. Choat (unpubl. data). These data were then converted to biomass estimates using length-weight relationships (Choat \& Axe 1996, Choat et al. 1996) and multiplied by annual mortality rates to estimate turnover.

\section{RESULTS}

\section{Diet}

Mean values of material ingested by Salarias patzneri indicate that detritus represents more than 50\% of ingested matter for all fish size classes (Fig. 1). Inorganic sediment was the next largest category of ingested material, with a mean representation of 24 to $30 \%$ of the gut contents. In contrast, the mean percentage of filamentous algae in the guts of different size classes of $S$. patzneri was only 10 to $16 \%$. Filamentous blue-green algae, diatoms and invertebrates, predominantly copepods, made up the remainder of the ingested matter, although when combined, these dietary categories accounted for less than $5 \%$ of all ingested matter. Kruskal-Wallis tests found no significant differences in the relative amounts of detritus, sediment, filamentous algae, filamentous blue-green algae, diatoms and invertebrates ingested by the different size classes of fish (Table 1).

\section{Growth, mortality and turnover rates}

The otoliths collected from Salarias patzneri treated with tetracycline and held in an aquarium for $12 \mathrm{~d}$ did not produce a fluorescent band when viewed under UV light. However, when these otoliths were viewed under light transmitted from a standard microscope light bulb, there was a wide translucent band, 10 to 11 rings from the edge in all 5 of the treated fish. Although this does not definitively prove that rings on otoliths are daily, studies of other small-bodied fish have validated daily growth rings (e.g. Iglesias et al. 1997, Hernaman et al. 2000). Consequently, it was assumed that opaque rings on $S$. patzneri otoliths represent daily increments. 


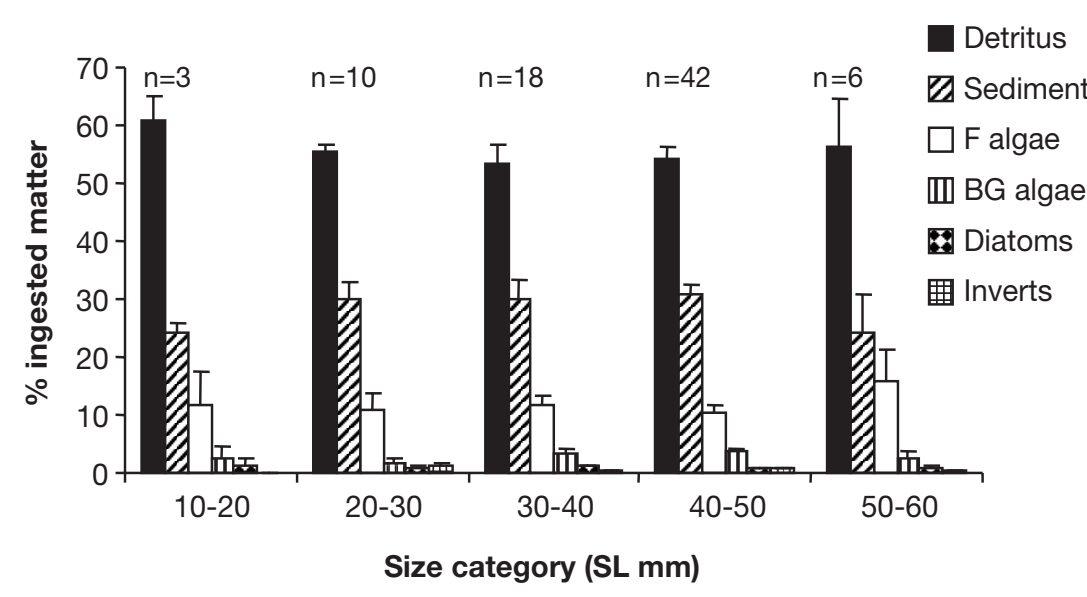

Fig. 1. Salarias patzneri. Gut content analysis. Error bars are standard errors, based on the number of fish analyzed in each size category. Figures above each size category are the number of fish analyzed in that size category. $\mathrm{F}$ algae $=$ filamentous algae, BG algae = blue-green algae, Inverts = invertebrates

Table 1. Salarias patzneri. Summary statistics from KruskalWallis test comparing gut contents in 5 different size categories. See Fig. 1 for gut content data

\begin{tabular}{|lccc|}
\hline Ingested category & $H$ & df & $\mathrm{p}$ \\
\hline Detritus & 1.74 & 4 & 0.78 \\
Sediment & 2.90 & 4 & 0.57 \\
Filamentous algae & 1.39 & 4 & 0.85 \\
Blue-green algae & 1.93 & 4 & 0.75 \\
Diatoms & 2.36 & 4 & 0.67 \\
Invertebrates & 3.03 & 4 & 0.55 \\
\hline
\end{tabular}

Of the 109 Salarias patzneri aged, there were no fish with more than 365 bands on their otoliths. The largest (SL $58.8 \mathrm{~mm}$ ) and oldest individual collected was estimated to be $340 \mathrm{~d}$, or $0.93 \mathrm{yr}$, old. In contrast, it was estimated that the smallest (SL $11.0 \mathrm{~mm}$ ) fish was only $42 \mathrm{~d}$ old. Many of the larger fish also had well-developed gonads, and in female gonads eggs were visible, indicating that they were mature fish. A von Bertalanffy model with the parameter estimates $L_{\infty}=$ $51.0 \mathrm{~mm} \mathrm{SL}, K=3.25 \mathrm{yr}^{-1}$ and $t_{0}=0.06 \mathrm{yr}$ explained $73 \%$ of the variation in length-at-age data for S. patzneri. When this model was plotted over the length-at-age data it was apparent that growth of $S$. patzneri is continuous and that asymptotic size has not been reached (Fig. 2).

Using the parameters from the von Bertalanffy equation and the Pauly (1980) method, the mortality rate of $S$. patzneri was estimated to be $6.37 \mathrm{yr}^{-1}$. Expressed as a percentage, this value represents $0.2 \% \mathrm{yr}^{-1}$ survivorship. Using the Hoenig (1983) method, estimates of mortality and survivorship were $5.95 \mathrm{yr}^{-1}$ and $0.3 \%$ $\mathrm{yr}^{-1}$, respectively. Thus both methods estimate that mortality rates are high and that less than $1 \%$ of the population is likely to survive longer than a year.

Estimates of Salarias patzneri density on reefs during the summer were more than twice those in the winter (Table 2). Wet weight of individual fish was calculated using the relationship: weight $(\mathrm{g})=0.007 \mathrm{TL}(\mathrm{mm}) 3.09, \mathrm{r}^{2}=0.97$, which was derived from fish used in growth and diet analysis $(\mathrm{n}=109)$. As biomass estimates are based on total length and growth analysis on standard length the equation: SL $(\mathrm{mm})=0.84 \mathrm{TL}$ $(\mathrm{mm})-0.39, \mathrm{r}^{2}=0.99$, is provided to allow conversion between the 2 length estimates.

Using the wet weight of individual fish, it was estimated that the biomass of Salarias patzneri was twice as high in the summer as it was in the winter. Consequently, based on biomass and mortality estimates, turnover rates of $S$. patzneri were greater in the summer. The summer turnover rates of $S$. patzneri were similar to those of the detritivorous scarid Chlorurus schlegeli and herbivorous Acanthurus lineatus. However, the highly abundant Ctenochaetus striatus and Chlorurus sordidus had turnover rates that were respectively 3 and 6 times greater than the $S$. patzneri rate. The other 2 acanthurids, Naso unicornis and Zebrasoma scopas, had turnover rates lower than the summer estimate for S. patzneri (Table 2).

\section{DISCUSSION}

The small salariin blenny Salarias patzneri maintains continuous growth on a detritus-based diet, a finding that provides further evidence that detritus is a highly nutritious dietary resource on coral reefs. Fish in all size classes, from the young juveniles to the largest fish sampled, ingested more detritus than any other dietary category. Indeed, the amount of detritus ingested did not vary significantly amongst the size categories, suggesting that there is no ontogenetic shift in the diet of S. patzneri post-settlement. Previous studies have demonstrated that detritus is a dietary resource with a nutritional value comparable to, if not better than, filamentous algae collected from the same fish territory (Wilson \& Bellwood 1997, Crossman et al. 2001) and that detritus collected from $S$. patzneri territories has low $\mathrm{C}: \mathrm{N}$ ratios, high organic content and high proteinenergy ratios, indicating that it is of high nutritional value (Wilson 2000, 2002). S. patzneri selectively feed 


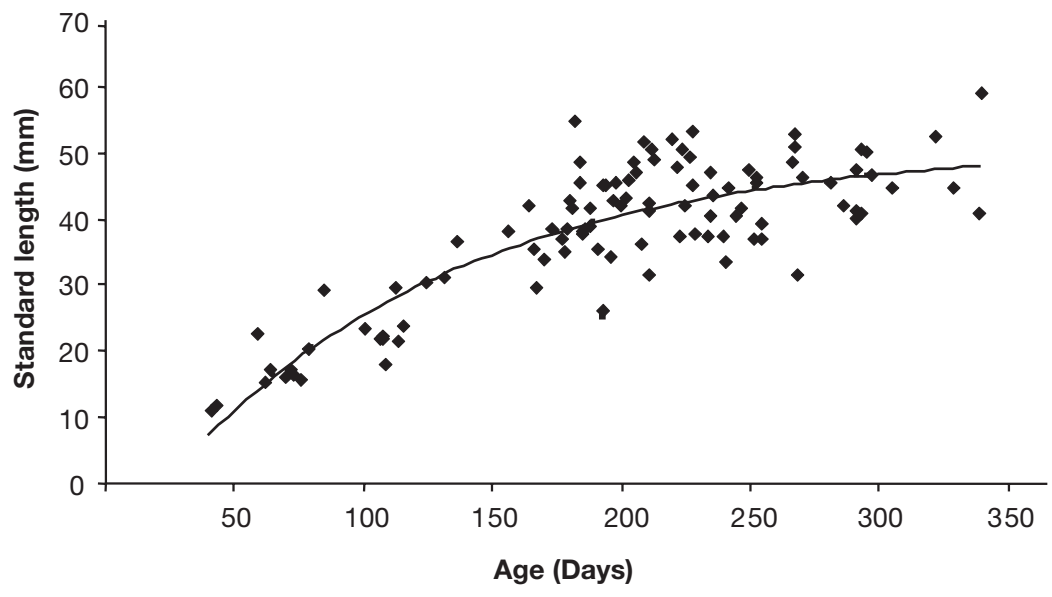

Fig. 2. Salarias patzneri. Length-at-age data. Fitted line is von Bertalanffy model, $\mathrm{r}^{2}=0.73 . \mathrm{n}=109$ chaetus striatus and Chlorurus sordidus are the most abundant acanthurid and scarid respectively on exposed and semi-exposed reefs at Lizard Island (Choat \& Bellwood 1985, Gust et al. 2001), as well as many other coral reefs throughout the Indo-Pacific (Russ 1984, McClanahan 1994, Jennings et al. 1996, Sluka \& Miller 2001). Both have maximum body weights 2 to 3 orders of magnitude greater than $S$. patzneri, yet turnover rates of all 3 species are of the same order of magnitude.

The turnover rates of Salarias patzneri are based on density estimates from a single summer and winter. Density estimates are higher in the summer, when recruitment of juvenile on small detrital particles, which are also the major source of organic matter in EAM samples collected from within their territories (Wilson 2000). Furthermore, salariin blennies have a relatively long, yet simple alimentary canal, with gut throughput rates that may be as short as $1 \mathrm{~h}$ (M. Marnane unpubl. data). Consequently, high gut throughput rates, combined with selective feeding on detritus of a high nutritional value, allow these fish to not only satisfy the high metabolic demands associated with small body size, but also sustain continuous growth throughout postsettlement life history.

The high density and short lifespan of Salarias patzneri combine to produce relatively high turnover rates in this species. Indeed, turnover rates of this small cryptic blenny are comparable to those of large, abundant fish that feed on the EAM at Lizard Island. Cteno- blennies is typically high (Labelle \& Nursall 1992, Wilson \& Meekan 2001), whilst lower densities in the winter are most likely due to high mortality. Density estimates of $S$. patzneri are similar to those of other salariin blennies on artificial reefs constructed at One Tree Island (mean density of 3 to 11 fish per $1.0 \times 0.8 \times$ $0.7 \mathrm{~m}$ reef; St John et al. 1990), shallow reefs in Barbados (0.6 to 4.0 fish $\mathrm{m}^{-2}$; Labelle \& Nursall 1992) and 3 reefs from the Southern Great Barrier Reef (mean densities of 0.1 to 0.8 fish $\mathrm{m}^{-2}$; Townsend \& Tibbetts 2000), suggesting that high densities of blennies are not uncommon on coral reefs and that these fish are important trophic links between detritus and secondary consumers. Temporal variation in recruitment of $S$. patzneri may, however, affect abundance of this species, which would ultimately affect turnover rates. Similarly, spatial variation in the abundance of blennies

Table 2. Mortality, density, biomass and turnover estimates for Salarias patzneri and prominent acanthurids and scarids at Lizard Island. Mortalities of acanthurids and scarids were calculated from data in Choat \& Axe (1996) and Choat et al. (1996). Density estimates of acanthurids and scarids were provided by J. H. Choat (unpubl. data). Classification of acanthurids and scarids as detritivores or herbivores is based on Choat et al. (2002). S, summer; W, winter. Values in parentheses are standard errors (SE), estimates of turnover SE calculated from variation SE about mean biomass estimates

\begin{tabular}{|c|c|c|c|c|c|c|}
\hline \multirow[t]{2}{*}{ Species } & \multicolumn{2}{|c|}{ Mortality } & \multirow{2}{*}{$\begin{array}{l}\text { Survival } \\
\left(\% \mathrm{yr}^{-1}\right)\end{array}$} & \multirow{2}{*}{$\begin{array}{c}\text { Density } \\
\left(\mathrm{m}^{-2}\right)\end{array}$} & \multirow{2}{*}{$\begin{array}{c}\text { Bio- } \\
\text { mass } \\
\left(\mathrm{g} \mathrm{m}^{-2}\right)\end{array}$} & \multirow{2}{*}{$\begin{array}{c}\text { Turnover } \\
\left(\mathrm{g} \mathrm{m}^{-2}\right. \\
\left.\mathrm{yr}^{-1}\right)\end{array}$} \\
\hline & $\begin{array}{c}Z \\
\left(\mathrm{yr}^{-1}\right)\end{array}$ & $\begin{array}{l}\text { Relative } \\
\left(\% \mathrm{yr}^{-1}\right)\end{array}$ & & & & \\
\hline \multicolumn{7}{|l|}{ Detritivores } \\
\hline Salarias patzneri (Summer) & 5.95 & 99.7 & 0.3 & $0.413(0.047)$ & $0.255(0.045)$ & $0.255(0.045)$ \\
\hline (Winter) & 5.95 & 99.7 & 0.3 & $0.166(0.015)$ & $0.104(0.009)$ & $0.103(0.009)$ \\
\hline Ctenochaetus striatus & 0.12 & 11.4 & 88.6 & $0.092(0.007)$ & $6.419(0.643)$ & $0.732(0.073)$ \\
\hline Chlorurus schlegeli & 0.58 & 44.0 & 56.0 & $0.006(0.002)$ & $0.523(0.165)$ & $0.230(0.073)$ \\
\hline Chlorurus sordidus & 0.46 & 36.6 & 63.4 & $0.017(0.002)$ & $4.198(2.533)$ & $1.537(0.927)$ \\
\hline \multicolumn{7}{|l|}{ Herbivores } \\
\hline Acanthurus lineatus & 0.09 & 8.5 & 91.5 & $0.023(0.007)$ & $2.817(0.820)$ & $0.239(0.070)$ \\
\hline Naso unicornis & 0.27 & 23.9 & 76.1 & $0.005(0.003)$ & $0.538(0.255)$ & $0.129(0.061)$ \\
\hline Zebrasoma scopas & 0.12 & 11.7 & 88.3 & $0.016(0.002)$ & $1.642(0.209)$ & $0.192(0.024)$ \\
\hline
\end{tabular}


and other detritivores may influence the relative importance of blennies in transferring energy to higher trophic levels. Further studies examining both temporal and spatial variations in blenny populations on coral reefs are therefore needed to determine whether these species have consistently high turnover rates and whether they represent a stable link between detritus and secondary consumers over extended temporal and spatial scales.

Further evidence that salariin blennies provide an important link between detritus and secondary consumers comes from information on the diets of predatory fish. Blennies have been identified as important prey items of common coral reef fish from the families Serranidae and Lutjanidae (Kingsford 1992, Connell 1998, St John 1999), as well as primary prey of specialized predatory fish from the families Aulostomidae and Fistulariidae (Hiatt \& Strasburg 1960, Randall 1967). Although these studies did not distinguish between different species of blennies, the prevalence of blennies in a range of predator guts, the common occurrence of these predators on reefs and the high mortality rates of Salarias patzneri emphasize the significance of salariin blennies to coral reef trophodynamics.

Overall, this study has demonstrated that the smallbodied, salariin blenny Salarias patzneri sustains continuous growth from juvenile to adult on a detritusbased diet, supporting previous findings that detritus is a nutritionally valuable dietary resource for coral reef fish. High turnover rates of detritivorous fish, small and large, also indicate that detritivory by fish represents a major mode of energy transfer on coral reefs.

Acknowledgements. This manuscript was greatly improved by discussions with J. H. Choat, M. Depczynski, R. Fisher, M. Marnane, D. Wilson and 3 anonymous reviewers. I am grateful for the support of staff at the Lizard Island Research Station and assistance from K. Buckley, R. Fisher, M. Marnane, M. Pratchett and R. Thomas whilst in the field. J. Ackerman and W. Robbins provided advice on fitting growth models to length-at-age data and J. H. Choat provided data on the size and density of acanthurids and scarids. I would also like to gratefully acknowledge the key financial support provided by The School for Field Studies (SFS), Center for Marine Resource Studies, South Caicos. This projected was conducted under Great Barrier Reef Marine Park Authority permit G97/431.

\section{LITERATURE CITED}

Choat JH (1991) The biology of herbivorous fishes on coral reefs. In: Sale PF (ed) The ecology of fishes on coral reefs. Academic Press, San Diego, p 120-155

Choat JH, Axe LM (1996) Growth and longevity in acanthurid fishes; an analysis of otolith increments. Mar Ecol Prog Ser 134:15-26

Choat JH, Bellwood DR (1985) Interactions amongst herbivorous fishes on a coral reef: influence of spatial variation. Mar Biol 89:221-234
Choat JH, Robertson DR (2002) Age-based studies. In: Sale PF (ed) Coral reef fishes. Academic Press, San Diego, p $57-80$

Choat JH, Axe LM, Lou DC (1996) Growth and longevity in fishes of the family Scaridae. Mar Ecol Prog Ser 145:33-41

Choat JH, Clements KD, Robbins WD (2002) The trophic status of herbivorous fishes on coral reefs. Mar Biol 140: 613-623

Clarke A, Johnston NM (1999) Scaling of metabolic rate with body mass and temperature in teleost fish. J Anim Ecol 68: 893-905

Clements KD (1991) Gut microorganisms of surgeonfishes (Family Acanthuridae). PhD thesis, James Cook University of North Queensland, Townsville

Connell SD (1998) Patterns of piscivory by resident predatory fish at One Tree Reef, Great Barrier Reef. Mar Freshw Res 49:25-30

Crossman DJ, Choat JH, Clements KD, Hardy T, McConochie J (2001) Detritus as food for grazing fishes on coral reefs. Limnol Oceanogr 46:1596-1605

Depczynski M, Bellwood DR (2003) The role of cryptobenthic reef fishes in coral reef trophodynamics. Mar Ecol Prog Ser 256:183-191

Gust N, Choat JH, McCormick MI (2001) Spatial variability in reef fish distribution, abundance size and biomass: a multi-scale analysis. Mar Ecol Prog Ser 214:237-251

Hatcher BG (1981) The interaction between grazing organisms and the epilithic algal community of a coral reef: a quantitative assessment. Proc 4th Int Coral Reef Symp, Manila 2:515-524

Hernaman V, Munday PL, Schlappy ML (2000) Validation of otolith growth-increment periodicity. Mar Biol 137:715-726

Hiatt RW, Strasburg DW (1960) Ecological relationships of the fish fauna on coral reefs of the Marshal Islands. Ecol Monogr 30:65-127

Hoenig JM (1983) Empirical use of longevity data to estimate mortality rates. Fish Bull 81:898-903

Iglesias M, Brothers EB, Morales-Nin B (1997) Validation of daily increment deposition in otoliths: age and growth determination of Aphia minuta (Pisces: Gobiidae) from the northwest Mediterranean. Mar Biol 129:279-287

Jennings S, Boulle DP, Polunin VC (1996) Habitat correlates of the distribution and biomass of Seychelles' reef fish. Environ Biol Fish 46:15-25

King M (1995) Fisheries biology, assessment and management. Fishing News Books, Blackwell Science, Oxford

Kingsford MJ (1992) Spatial and temporal variation in predation on reef fishes by coral trout (Plectropomus leopardus, Serranidae). Coral Reefs 11:193-198

Labelle M, Nursall JR (1992) Population biology of the redlip blenny, Ophioblennius atlanticus macclurei (Sylvester) in Barbados. Bull Mar Sci 50:186-204

Marnane MJ (2001) The trophic role of cardinalfishes (Family Apogoniidae) on coral reefs. PhD thesis, James Cook University of North Queensland, Townsville

McClanahan T (1994) Kenyan coral reef lagoon fish: effects of fishing, substrate complexity, and sea urchins. Coral Reefs 13:231-241

Meekan MG, Ackerman JL, Wellington GM (2001) Demography and age structures of coral reef damselfishes in the tropical eastern Pacific Ocean. Mar Ecol Prog Ser 212: 223-232

Milton P (1983) Biology of littoral blenniid fishes on the coast of south-west England. J Mar Biol Assoc UK 63:223-237

Munday PL, Wilson SK (1997) Comparative efficacy of clove oil and other chemicals in anaesthetization of Pomacentrus amboinensis, a coral reef fish. J Fish Biol 51:931-938 
Pauly D (1980) On the interrelationships between natural mortality, growth parameters and environmental temperature in 175 fish stocks. J Cons 39:175-192

Randall JE (1967) Food habits of reef fishes of the West Indies. Stud Trop Oceanogr 5:665-847

Russ GR (1984) Distribution and abundance of herbivorous grazing fishes in the central Great Barrier Reef. I. Levels of variability across the entire continental shelf. Mar Ecol Prog Ser 20:23-34

Russ GR, St John J (1988) Diets, growth rates and secondary production of herbivorous coral reef fishes. Proc 6th Int Coral Reef Symp, Townsville 2:37-43

Santos RS, Nash RDM, Hawkins SJ (1995) Age, growth and sex ratio of the Azorean rook-pool blenny, Parrablennius sanguinolentus parvicornis. J Mar Biol Assoc UK 75: 751-754

Sluka RD, Miller MW (2001) Herbivorous fish assemblages and herbivory pressure on Laamu Atoll, Republic of the Maldives. Coral Reefs 20:255-262

Stephens JS, Johnson RK, Key GS, McCosker JE (1970) The comparative ecology of three sympatric species of California blennies of the genus Hypsoblennius Gill (Teleostomi, Blenniidae). Ecol Monogr 40:213-233

Stepien CA (1990) Population structure, diets and biogeographic relationships of a rocky intertidal fish assemblage in central Chile: high levels of herbivory in a temperate system. Bull Mar Sci 47:598-612

St John J (1999) Ontogenetic changes in the diet of the coral reef grouper, Plectropomus leopardus (Serranidae): patterns in taxa, size and habitat prey. Mar Ecol Prog Ser 180: 233-246

St John J, Russ GR, Gladstone W (1990) Accuracy and bias of visual estimates of numbers, size structure and bio-

Editorial responsibility: Otto Kinne (Editor),

Oldendorf/Luhe, Germany mass of a coral reef fish. Mar Ecol Prog Ser 64:253-262 Townsend KA, Tibbetts IR (2000) Biomass and distribution of herbivorous blennies in the southern Great Barrier Reef. J Fish Biol 56:774-791

Wilson DT, Meekan MG (2001) Environmental influences on patterns of larval replenishment in coral reef fishes. Mar Ecol Prog Ser 222:197-208

Wilson SK (2000) Trophic status and feeding selectivity of blennies (Blenniidae: Salariini). Mar Biol 136:431-437

Wilson SK (2001a) Multiscale habitat associations of detritivorous blennies (Blenniidae: Salariini). Coral Reefs 20: $245-251$

Wilson SK (2001b) An investigation into the trophic nature of small reef fish from the tribe Salariini, family Blenniidae. PhD thesis, James Cook University of North Queensland, Townsville

Wilson SK (2002) Nutritional value of detritus and algae in blenny territories on the Great Barrier Reef. J Exp Mar Biol Ecol 20:245-251

Wilson SK, Bellwood DR (1997) Cryptic dietary components of territorial damselfishes (Pomacentridae, Labroidei). Mar Ecol Prog Ser 153:299-310

Wilson SK, Burns K, Codi S (2001) Sources of dietary lipids in the coral reef blenny Salarias patzneri. Mar Ecol Prog Ser 222:291-296

Wilson SK, Bellwood DR, Choat JH, Furnas M (2003) Detritus in the epilithic algal matrix and its use by coral reef fishes. Oceanogr Mar Biol Annu Rev 41:279-309

Worthington DG, Doherty PJ, Fowler AJ (1995) Variation in the relationship between otolith weight and age: implications for the estimation of age of two tropical damselfish (Pomacentrus moluccensis and P. wardi). Can J Fish Aquat Sci 52:233-242

Submitted: February 23, 2004; Accepted: August 26, 2004 Proofs received from author(s): December 8, 2004 
